\title{
Governance in Land Acquisition Process: A Study on Shreehatta Economic Zone, Moulovibazar
}

\author{
Sabina Yasmin* (Corresponding Author) \\ Assistant Professor \\ Department of Public Administration \\ Shahjalal University of Science and Technology, Sylhet-3114, Bangladesh \\ E-mail: syasminpad14@gmail.com
}

\begin{abstract}
Ruhi Begum**
MSS Research Student

Department of Public Administration

Shahjalal University of Science and Technology, Sylhet-3114, Bangladesh

E-mail: ruhisust230@gmail.com

Muhammad Mustofa Kamal***

Assistant Professor

Department of Public Administration

Shahjalal University of Science and Technology, Sylhet-3114, Bangladesh

E-mail: mustafapadsust@gmail.com
\end{abstract}

Received: March 4, 2020 Accepted: March 23, 2020 Online published: May 12, 2020

doi:10.5296/jpag.v10i2.17015

URL: https://doi.org/10.5296/jpag.v10i2.17015

\begin{abstract}
Land acquisition in Bangladesh for development activities is considered a critical issue. This study attempts to explore the existing scenario of the governance in the land acquisition process at Shreehatta Economic Zone, Moulovibazar, Bangladesh. This study is based on both the primary and secondary sources of data. The primary data was collected from 55
\end{abstract}


respondents which include both administrative officials and the project affected people and the secondary data was collected from different renowned journals, official documents of the administration, newspapers, and other relevant sources. The study reveals that there exists malpractices in the land acquisition process, where project-affected people do not get fair compensation and they are forced to pay bribe for getting compensation. In spite of having national and international guidelines for land acquisition, officials unethically acquire the agricultural land by misusing their discretionary power which leads the project affected people to more vulnerability.

Keywords: governance, corruption, land acquisition, Special Economic Zone (SPZ), project affected people

\section{Introduction}

The land is one of the crucial disputed issues of public policies throughout the world which is the prime source of food and habitation of the populace (Parwez \& Sen, 2016). Land acquisition, displacement, resettlement, rehabilitation, and compensation are considered complex matters of public administration which can result in the loss of income and the rise of inequality in the society (Kurian, $2000 \&$ World Bank, 2008). The compulsory acquisition of land for development purposes has always been a common issue and it is increasing in the context of rapid growth (FAO, 2008).

Land acquisition for a development project is not a new topic of discussion especially in a developing country like Bangladesh. Thus, land acquisition by the authority for any purpose is seen as a vital issue in Bangladesh. But in a land-hungry country like- Bangladesh, land acquisition means something threatening and frightening to land owners. In almost all cases, owners are completely against the land sale though land acquisition is essential for the holistic development and acceleration of the economic growth of the country.

Currently, the total size of the population of Bangladesh is 16.56 crore, population density per sq. $\mathrm{km}$ is 1116 , the GDP growth rate is 8.15 percent, and the per capita national income is US\$1,909 (BBS, 2020). However, to meet the growing demand of its huge population and to continue the prevailing GDP growth, the government of Bangladesh is badly in need of rapid industrialization and establishment of additional government nation-building departments and for this reason the government has to acquire land compulsorily (Athahar, 2013) where a land owner can't deny quitting the right of his land after the decision is taken by the government to acquire it for any crucial development project (FAO, 2008).

The District Land Allocation Committee (DLAC) and the Central Land Allocation Committee (CLAC) were established in Bangladesh in 1976 for optimal utilization of most precious property which is also responsible for land allocation at the district level. The DLAC is the decision making authority of land acquisition at the district level while the CLAC is that of at the central level (Athahar, 2013). However, the study of Athahar described the land acquisition process in Bangladesh as "two bodies have worked together to acquire land: the Requiring Body $(R B)$ and the Acquiring Body $(A B)$, which provide legal and technical assistance, respectively. After fulfilling certain obligations as required by law, the process 
starts with the RB. Finally, the DC acquires the land, and compensation is paid by the DC's office. However, according to the law, there is no definitive method of payment of compensation. Once compensation is paid, the ownership transfers to the RB" (Athahar, 2013, p. 309).

Although article-42(2) of the Constitution of the People's Republic of Bangladesh provides the guaranty of paying adequate compensation against concerning land acquisition, corrupt officials manipulate the process and deprive the land owners of their fair compensation (TI, 2011). This arbitrary practice of inappropriate payment reduces the public confidence and creates social anarchy between the authority and the project affected people (FAO, 2009). In this context, people demand a fair process of land acquisition for ensuring sustainable development in true sense. This study reviews the current situation of the land acquisition process and the existing unethical practices in this sector.

\section{Objectives of the Study}

This study attempted to explore the existing scenario of governance in the land acquisition process at Shreehatta Economic Zone, MoulviBazar, Bangladesh. To fulfill the main objective, there were some specific objectives too which include:

- To find out the accountability and transparency in the land acquisition process in Bangladesh with a special reference to the Special Economic Zone (SPZ) in Moulvibazar district.

- To know the type of land acquired for Special Economic Zone (SPZ) in Moulvibazar district.

\section{Review of Relevant Literature}

The land is a permanent asset and it cannot be used up as other development materials. Land acquisition stands for the process through which the government acquires private land perforce for a public purpose with or without the consent of the owner of the land (Basu, 2007 \& Chandrashekhar, 2009). The land acquisition process of the government of Bangladesh is depicted in Article 42 of The Constitution of the People's Republic of Bangladesh. The article poses that the constitution of Bangladesh provides the citizens with the fundamental right to possess, gain, retain, transmit, or otherwise dispose of property, side by side the article also acknowledges the utmost authority of the state to acquire any piece of land by providing compensation, if the state needs. In other words, the government has the power to acquire any land by constraint. The acquisition process of land and other assets for development purposes denies people of their livelihood. Sometimes people are displaced and deprived of their livelihood without managing any second location (Fernandes et al, 2012). Most of the acquired land for a development project is agricultural land which might be hazardous for the country's sustainable development (Rahman, 2013). The impacts of land acquisition are huge. In most cases, people lose their most valuable homestead and farmland but are paid with poor compensation; and consequently, lose their earning source which pushed them into the trap of poverty (Atahar, 2013). The affected people are not only suffered by forceful eviction and restatement but also deprived of getting fair compensation (Rahman, 
2013). And the payment of compensation for land varies, according to tenure status and ownership rights. As a result, compensation paid for the land and other assets is typically less than replacement or market value (Zaman, 2002).

On the contrary, only financial compensation is not sufficient to rebuilt project-affected persons' (PAPs) livelihoods, often shattered by development projects (Cernea \& Mathur, 2009). The impact of SEZ on rural employment can be viewed as negative in the sense that it may create a labor shortage and deprive rural areas of the youngest and best-educated people (Parwez \& Sen, 2016). Land acquisition often results in indecent outcomes; socio-economic conditions get deteriorated and displacement is a corollary of development policies (Karmakar, 2017). Padma Multipurpose Bridge Project (PMBP) can be a good example of one of the biggest land acquisition projects in Bangladesh. This project has acquired the land from three districts namely from Munshiganj, Madaripur, and Sherpur districts which fall in the southern part of Bangladesh.It has created a positive impact on people's living status. Project-affected people have been paid high value against their hardly cultivable land.The government has taken various positive measures during the implementation phase of this development project and after its successful implementation, the socio-economic effect would be much higher. For example, The government has built seven residential areas spending Tk 165.62 crore for the residents affected by land acquisition of Padma bridge construction and essential river training work. And all the civic facilities have been ensured in every Resettlement Site(RS). People whose lands were acquired by the government and who had no other land for dwelling were also awarded plots in RS. And for the last few years, a socio-economic transition is being noticed in those areas, mainly because of the cash disbursement against the land acquisition for the Padma bridge project. Till October 2018, the value of the land acquired for the Padma bridge project stood at Tk 2358.77 crore. The government has paid out Tk 638.98 crore among the affected families till February 2019. According to the Padma Multipurpose Bridge Project (PMBP) data, around one lakh people of 16,340 families have been affected directly by the land acquisition for the Padma bridge construction. The government has developed 2906 plots of three different sizes (of 2.5 decimal, 5.0 decimal, and 7.5 decimal) in these Resettlement Sites (RS) for the affected people (Dhaka Tribune, April 13, 2020).

Land administration has been identified as a sector with high malpractice risk in Bangladesh. It is often quoted that households in Bangladesh are sometimes bound to pay the bribe or illegal money to land administration to get service in return while the non-payers face harassment (TI, 2011). In this reality, an assumption has been created among the people that the land sector is not free from corruption and it threatens almost all economic sectors of the country. For these unfair practices in the land sector, the government land acquisition process is criticized in every sector. This misuse of power by the government officials turns the development project into a curse for the project affected people. In many cases, officials create artificial problems and force the people to pay bribe which leaves the common people very helpless. 


\section{Methodology of the Study}

Research methodology demonstrates what systematic procedures and techniques are followed for the validity of the study being conducted. This study uses a combination of qualitative and quantitative methods. The study was conducted at the Shreehatta Economic Zone, which is established on 352 acres of land at Moulvibazar Sadar Upazila under the Moulovibazar District. Honorable Prime Minister of Bangladesh, Sheikh Hasina, laid the foundation stone of Shreehatta Economic Zone's development work in February 2016 (Bangladesh Economic Zones Authority (BEZA, 2019).

This research is exploratory and descriptive in form based on primary and secondary data. The population of this study consisted of all officials working in the office of the Deputy Commissioner (DC), Moulvi Bazar District, and the people who were affected due to land acquisition for the establishment of the Shreehatta Economic Zone. Primary data was collected from the concerned administrative officials of land acquisition authority and the project-affected people, using a structured interview schedule with both closed and open-ended questions. On the other hand, secondary data was collected from published books, journals, articles, periodicals, newspapers, the internet, and relevant organizations.

In this study, data were collected from fifty-five (55) individuals which include five (05) officials i.e. Deputy Commissioner, Additional Deputy Commissioner (Revenue), Land Acquisition Officer, Surveyor, Kanungo who were directly involved in the land acquisition process and fifty (50) project-affected people. The administrative officials were selected purposively so that the most relevant data could be collected and project-affected people were selected using a systematic sampling method. Collected data were analyzed by Statistical Package for Social Science (SPSS) software.

\section{Operational Definition of Key Variables}

\subsection{Land Acquisition}

Land acquisition is a process where the government takes possession of the private ownership of land for public purposes. The government takes ownership of a land property for the greater interest of the country. In this research, land acquisition indicates the process under which the land of the special economic zone has been acquired. The Acquisition and Requisition of Immovable Property Act, 2017, Section 2(1) defines the term as: Acquisition means acquiring the ownership and possession of any immovable property for any requiring person or organization in exchange for compensation or rehabilitation or both (Islam, 2019).

\subsection{Governance}

The term governance encompasses all the processes of governing which are used by the government of a state to run the state affairs. It implies "how people are ruled, how the affairs of the state are administered and regulated as well as nation's system of politics and how these function to public administration and law" (Landell-Mills and Seragelding 1991, $p$. 304). In this research, governance denotes land governance which includes decisions on access to land, land rights, land use, and land development. Sound land governance is the key 
to the achievement of sustainable development.

The following working definition for land governance is proposed: "land governance concerns the rules, processes, and structures through which decisions are made about access to land and its use, how the decisions are implemented and enforced, the way that competing interests in land are managed" (Palmer et al, 2009, p. 9).

\subsection{Economic Zone}

Here, 'Economic Zone' means any industrial zone declared by the Government through gazette notification for attracting investments to the nation, industrializing the national economy, redressing the nation's intra-regional disparities and creating new employment opportunities for the nation. Special Economic Zone is considered an enormous investment in industrial infrastructure to attract and facilitate foreign investment, amalgamate local firms into global value chains, uphold export-oriented growth and create employment which acts as an important tool for socio-economic development (Mazid, 2019).

\section{Findings of the Study}

In this research, the primary data have been collected by using semi-structured questionnaires from key respondents and asking a set of questions from officials' interviews. Here, the collected data have been organized characteristically, and then used statistical tools e.g. percentage analysis has been applied to them. Quantitative data have been presented in the tables and the responses are shown in percentage. The data of the table have been discussed then.

Table 6.1. Designation of the Respondent $(n=55)$

\begin{tabular}{|c|c|c|}
\hline Designation of Respondent & Number & Total \\
\hline \multicolumn{3}{|l|}{ Land Acquisition Officials } \\
\hline \multirow{5}{*}{$\begin{array}{ll}\text { - } & \text { DC (DeputyCommissioner) } \\
\text { - } & \text { ADC (Additional Deputy Commissioner)(Revenue) } \\
\text { - } & \text { LAO (Land Acquisition Officer) } \\
\text { - } & \text { Kanungo (Deputy Assistant Settlement Officer) } \\
\text { - Surveyor }\end{array}$} & 1 & \multirow{5}{*}{05} \\
\hline & 1 & \\
\hline & 1 & \\
\hline & 1 & \\
\hline & 1 & \\
\hline Project-Affected People (PAP) & 50 & 50 \\
\hline Total & & \\
\hline
\end{tabular}

Source: Field survey, Moulvibazar District, November-December, 2018

Data was collected from a different group of people (total 50 Project Affected People (PAP)) who were directly affected by the land acquisition process. On the other hand, five (05) administrative officials (including both gazetted and non-gazetted officials) were interviewed who were directly involved in the land acquisition process (Table 6.1). 
Table 6.2. Willingness to Transfer Land $(n=50)$

\begin{tabular}{|c|c|c|}
\hline Responses & No. of Respondents & $\begin{array}{c}\text { Percentage } \\
(\boldsymbol{\%})\end{array}$ \\
\hline Yes & 04 & $08.0 \%$ \\
\hline No & 22 & $44.0 \%$ \\
\hline Partially & 24 & $48.0 \%$ \\
\hline Total & 50 & $100 \%$ \\
\hline
\end{tabular}

Source: Field survey, Moulvibazar District, November-December, 2018

Being asked about the willingness to transfer the land, majority of the respondents (48\%) from the Project-affected People (PAP) said that they showed their partial willingness only when the authority made them understand that this project will create much employment opportunity and accelerate country's development. But (44\%) respondents replied that they were not willing to transfer their land. And only (8\%) replied that they transferred their land willingly (Table 6.2).

When a special economic zone is created, there arise often disputes over land acquisition, as it involves converting land from agricultural to industrial (IIED, 2018). The study also found that among the 352 acres of acquired land a large portion was agricultural ${ }^{1}$. To sum up, more than $80 \%$ of the acquired land is agricultural which is dangerous for a country's sustainable development. By principle, it should not take any kind of development project which will destroy the countryś the main strength of economy as the production of food and employment (Rahman, 2013).

Table 6.3. Fairness ${ }^{2}$ in Land Acquisition Process $(n=50)$

\begin{tabular}{|c|c|c|}
\hline Responses & No. of Respondents & $\begin{array}{c}\text { Percentage } \\
(\boldsymbol{\%})\end{array}$ \\
\hline Yes & 00 & $00.0 \%$ \\
\hline No & 38 & $76.0 \%$ \\
\hline Partially & 12 & $24.0 \%$ \\
\hline Total & 50 & $100 \%$ \\
\hline
\end{tabular}

Source: Field survey, Moulvibazar District, November-December, 2018

Throughout the interview, of the total respondents of the Project-Affected People (PAP), only (24\%) respondents expressed their partial satisfaction and stated that the land acquisition process was partially fair. But $(76 \%)$ of the respondents replied that the land acquired from them is ethically unfair and they stated that their only means of livelihood namely the land was acquired by the authority but their resettlement was not ensured. On the other hand, the

\footnotetext{
1 Agricultural land is generally land fixed for agriculture, the organized and restrained use of other forms of life especially the rearing of livestock and production of crops to produce food for humans. In this way, it is synonymous with farmland or cropland, as well as pasture or unimproved land that is suitable for the grazing of livestock.

${ }^{2}$ Fairness means equal treatment of all parties and rivals without being biased.
} 
most surprising fact is that there was no positive response in case of fairness in the acquisition process (Table 6.3).

The project-affected people blamed that administration acquired graveyard land paying no heed to their objection. It is contrary to the main theme of natural justice which normally refers to the "duty to act fairly" with the aims to prevent arbitrariness and injustice towards the citizens with an act of administrative authorities. It is a sense of what is wrong and what is right.

The traditional English law recognizes two principles of natural justice which are (i) the rule against bias (Nemo index in causa sua, or "no man a judge in his cause"), and (ii) the right to a fair hearing (Audi alteram partem, or "hear the other side"). The second fundamental principle of natural justice is no man should be condemned unheard or both sides must be heard before passing any order and this is also the basic requirement of rule of law. That's why the land acquisition by the administration without hearing the project-affected peoples' objection is contrary to the main theme of the Dicey's Rule of Law. Dicey stated that there must be equality before the law or the equal subjection of all classes to the ordinary law (Takwani, 1980).

Unjust system of compulsory land acquisition creates insecurity of land occupancy and heightens the tensions between the government and citizens by reducing public confidence towards the rule of law. On the other hand, corruption prevails where the procedures are unclear, unpredictable, and unenforceable (FAO, 2009).

On being interviewed, one of the officials who were directly engaged in the land acquisition process stated that:

"It's fair regarding the rationality of acquiring agricultural land for a Public-Private Partnership project for the development of a country. It's a common nature that project affected people always blame the authority" (Administrative officials, Interview 1, November 2018).

Table 6.4. Getting Compensation for Acquired Land $(\mathrm{n}=50)$

\begin{tabular}{|c|c|c|}
\hline Responses & No. of Respondents & $\begin{array}{c}\text { Percentage } \\
(\mathbf{\%})\end{array}$ \\
\hline Yes & 32 & $64.0 \%$ \\
\hline No & 13 & $26.0 \%$ \\
\hline Partially & 05 & $10.0 \%$ \\
\hline Total & 50 & $100 \%$ \\
\hline
\end{tabular}

Source: Field survey, Moulvibazar District, November-December, 2018

Being questioned about the compensation, (64\%) of the project-affected people replied that they got their compensation. And (10\%) of them replied that they got partial compensation. And (26\%) said against this. They said that they could not get their compensation due to various complications (Table 6.4). 
Land acquisition is getting a cantankerous issue day by day due to the insufficient compensation and loss of productive lands. The payment of compensation for land depends on the tenure status of the land and the amount of compensation is generally less than the market value (Zaman, 2002).

Regarding the land acquisition process, the fair compensation principle is not in place and there exist variations in the compensation standard (Chan, 2003). Due to the complex and prolonged process, the project-affected people lose their interest to receive the total compensation. In every step of the process, they face so many obstacles in collecting their compensation money. In most cases, land owners have to spend (30-50) percent of compensation money on bribing the concerned officials (Mamun \& Alam, 2019). And finally, they lose interest to go to the office for collecting compensation money (Atahar, 2013).

Table 6.5. Involvement in Determining Compensation $(n=50)$

\begin{tabular}{|c|c|c|}
\hline Responses & No. of Respondents & $\begin{array}{c}\text { Percentage } \\
(\mathbf{\%})\end{array}$ \\
\hline Yes & 00 & $00.0 \%$ \\
\hline No & 50 & $100.0 \%$ \\
\hline Partially & 00 & $00.0 \%$ \\
\hline Total & 50 & $100 \%$ \\
\hline
\end{tabular}

Source: Field survey, Moulvibazar District, November-December 2018

In response to the question of engagement of the project-affected people in determining compensation, all the respondents (100\%) from the project affected people replied that they were not involved in the compensation determination process and added that government officials determined it and informed them after the determination. And there was no response in case of whether they were engaged or partially engaged in this process because they were not aware of the rules and regulations of the acquisition process (Table 6.5).

Bangladesh is practicing the land acquisition process without proper legislation and estimates unfair compensation by using an inappropriate valuation method. Without having any appropriate law the land acquisition system in Bangladesh is unjustified. It is most essential to develop the law regarding the compulsory purchase to establish a fair and justified process and protect the right of ownership (Rahman, 2013).

To ensure accountability and transparency in the land acquisition process, citizens must have the knowledge of the Acquisition and Requisition Act which will help them to gather more information about the project and to express their thoughts and opinions about the compensation. If they are more conscious about their rights, they will act as a watchdog agency to reduce the chances of corruption.

But officials completely deny this objection as one of the respondents opined that:

"Citizens were involved in the process of determining compensation. We conducted a public meeting before determining the compensation. And the government allocate adequate funds for land acquisition and undoubtedly the acquisition and requisition 
of immovable property act 2017, increase compensation for land acquisition by the government up to triple the value of the property" (Administrative officials, Interview 2, November 2018).

We get the same information from the act (The Immovable Property Acquisition and Requisition Act-2017). The act proposed to pay thrice as high as the market value of the land acquired by the government as compensation for the owners (The Daily Star, April 4, 2017).

The land acquisition act ensures compensation for lands and fixed assets but there is no proper way to fix the lost income and livelihood of the project affected people and no proper initiatives to manage the source of income and livelihood.

Table 6.6. Satisfaction with Given Compensation $(n=50)$

\begin{tabular}{|c|c|c|}
\hline Responses & No. of Respondents & $\begin{array}{c}\text { Percentage } \\
(\boldsymbol{\%})\end{array}$ \\
\hline Yes & 00 & $00.0 \%$ \\
\hline No & 41 & $82.0 \%$ \\
\hline Partially & 09 & $18.0 \%$ \\
\hline Total & 50 & $100 \%$ \\
\hline
\end{tabular}

Source: Field survey, Moulvibazar District, November-December, 2018

The result shows that most of the respondents $(82 \%)$ asserted that the monetary compensation that they received against their land loss was not enough at all against their losses. They opined that it was not possible to buy the same quantity of land with compensation money. On the contrary, only $(18 \%)$ respondents stated that they were partly satisfied with the given money (Table 6.6).

But the real picture is different. Although The Immovable Property Acquisition and Requisition Act-2017 secure the provision of assessment for compensation of the property thrice as high as its market value, but in this project the land was acquired under the 1982 ordinance which secure the provision of assessment for compensation of the property one and half as high as its market value. Furthermore, in most of the cases, people suffer for their faults. People often lessen their land price in transactions to pay lower registration fees and taxes and as the government pays compensation as per the land value according to the land registry office which is valued by Government agencies results in less recompense for land than the replacement value of the property.

From the field survey, it is also found that people who lost their dwelling house for SEZ do not get their proper compensation as the administration provides only the value of structure and land compensation determined by the counting SA Khatiyan (Settlement Attestation was prepared under the State Acquisition and Tenancy Act 1950) record where the land was recorded as agricultural land or waste land. Some respondents also specified that they did not get their compensation due to false documentation. ${ }^{3}$

\footnotetext{
${ }^{3}$ False documentation is a criminal offense that involves the altering, changing, modifying, passing, or
} 
As the aim of the acquisition is to support the development and since there are strong logics for compensation to develop the position of those affected anywhere possible, legislation should ensure fair processes for determining compensation. Besides, people should receive proper recompense for the loss resulting from the compulsory acquisition of their land (FAO, 2009).

Table 6.7. Appeal against the Decision of Compensation $(n=50)$

\begin{tabular}{|c|c|c|}
\hline Responses & No. of Respondents & $\begin{array}{c}\text { Percentage } \\
(\%)\end{array}$ \\
\hline Yes & 11 & $22.0 \%$ \\
\hline No & 39 & $78.0 \%$ \\
\hline Partially & 00 & $00.0 \%$ \\
\hline Total & 50 & $100 \%$ \\
\hline
\end{tabular}

Source: Field survey, Moulvibazar District, November-December, 2018

From the field survey, it has been noticed that only (22\%) of the total respondents from the Project-Affected People (PAP), confirmed that they appealed against the decision of the authority but in vain as the high court refused the writ against it. On the other hand, (78\%) of the respondents informed that they did not have any idea of how to challenge the decision of the authority and they were forced to accept only what the acquiring agency had offered (Table 6.7).

A fair land-acquisition process plays an important role in building development projects. But corruption becomes an essential part in the process of compensation payment of the acquired land. Here, a section of people and land officials are involved in the process of delaying the payment of compensation, that's why some people file petitions with land offices and claiming ownership or title over the property. For this reason, many real landlords have to move to court for the determination of title over the property, causing a delay in compensation payment (Mamun \& Alam, 2019). So, legislation should offer opportunities for land owners to appeal against the compulsory land acquisition procedures which will help to protect the rights of affected people (FAO, 2009).

Table 6.8. Harassment in the Time of Acquisition $(n=50)$

\begin{tabular}{|c|c|c|}
\hline Responses & No. of Respondents & $\begin{array}{c}\text { Percentage } \\
(\boldsymbol{\%})\end{array}$ \\
\hline Yes & 46 & $92.0 \%$ \\
\hline No & 00 & $00.0 \%$ \\
\hline Partially & 04 & $08.0 \%$ \\
\hline Total & 50 & $100 \%$ \\
\hline
\end{tabular}

Source: Field survey, Moulvibazar District, November-December, 2018

possessing of a document for an unlawful purpose. 
From the field data, it was also found that almost all the respondents among the project-affected people (92\%) replied that they faced harassment at the time of land acquisition (like- the pressure of local elite to share the part of their compensation, to pay extra money to the personal assistant of the officials, complex procedure, etc). But only (8\%) respondents partially supported this statement (Table 6.8).

The respondents also added that they dropped complaints in the land acquisition office branch and district commissioner's office but they did not get any assistance. On the other hand, the respondents argued that they faced the problem of false documentation at the time of withdrawing compensation where government officials were engaged in this activity.

Table 6.9. Forced to Pay Bribes $(n=50)$

\begin{tabular}{|c|c|c|}
\hline Responses & No. of Respondents & $\begin{array}{c}\text { Percentage } \\
(\boldsymbol{\%})\end{array}$ \\
\hline Yes & 50 & $100.0 \%$ \\
\hline No & 00 & $00.0 \%$ \\
\hline Partially & 00 & $00.0 \%$ \\
\hline Total & 50 & $100 \%$ \\
\hline
\end{tabular}

Source: Field survey, Moulvibazar District, November-December, 2018

From the field survey, it was found that all of the respondents (100\%) among the project-affected people agreed that they were forced to pay bribes for issuing compensation checks. They also focused that public officials come to a secret understanding with local elites and develop artificial policies for their private gain as poorer people are unable to identify these unprofessional conducts and in such a way, they are always deprived of their rights. Moreover, people's access to information was also denied. The respondents also stated that they were bound to pay $(20-25 \%)$ of their total compensation as a bribe, even in some cases this amount raised to $(50 \%)$. They also added that they were forced to pay bribes not only at the time of getting compensation but also in every single stage of land acquisition like- to meet with officials, recording land type, getting any information, getting the application form, submitting the application etc (Table 6. 9).

Regarding this complain one official pointed out:

"The process of acquisition creates destruction for people who depend on the lands for a livelihood because brokers and politicians shake hands and take the money from the PAPs by pushing them towards poverty. And the ultimate blame comes upon us (administrative officials) who are involved in the land acquisition process. So I suggest that strict laws should be introduced which allows heavy penalties to be imposed on those middlemen who take the money illegally. If a person has strong ethical values s/he never engaged in it whatever s/he works. So, a department cannot be judged by the malpractice of some miscreants" (Administrative officials, Interview 3, November 2018).

Bribery in the land sector is not a regional problem rather an international phenomenon that we can learn from the following statement "Around the world, one in five people reports that 
they had paid a bribe for land services. The high percentage of bribery in the land sector creates a substantial informal cost for those trying to register or transfer land. It can make land services inaccessible to people who are not able to afford these illegal payments. By creating a disincentive to register property transactions, the informality of land tenure increases, people are left with little or no protection under the law, making them vulnerable to evictions and other abuses" (TI, 2013, p. 11). In most cases, land owners have to spend (30-50) percent of compensation money on bribing the concerned officials (Mamun \& Alam, 2019).

On being asked one of the officials demanded:

"We also take initiative to ensure accountability through the internal mechanism and also set a complaint dropping box for the general people to drop complaints against the officials for their malpractices"(Administrative officials, Interview 4, November 2018).

Complaints mechanisms can be a helpful tool to increase accountability and to detect corruption in land administration since they empower citizens to provide feedback on the quality and quantity of the services they receive and to submit complaints about wrongdoings. Moreover, user complaints can contribute to identifying sectors or areas particularly vulnerable to corruption (TI, 2018).

No truth of the official's demand is found in reality from the interviewees' comments. Moreover, interviewees report corruption related to the process of land allocation, land recovery, compensation, support, and resettlement. The most common form of corruption occurs in land offices is to receive bribes to facilitate access to information and services or favorable outcomes of administrative decisions in land valuation, development planning, and resolution of disputes or formal allocation of land rights (Owen et al., 2015). For these unethical practices in the land sector, government projects of land acquisition are criticized in every sector. "According to public opinion survey that is conducted in Bangladesh, the administrative corruption in the land sector is too much higher and results from a national household survey depicts that in Bangladesh, the land administration ranks among the top three institutions with the worst rates of bribery (71.2 percent) based on people who have had contact with the service" (TI, 2011, p. 3).

On the other hand, "Corruption in land administration can take different forms like complicated and expensive processes, a lack of information, exacerbate bribery in land services. As a consequence, people who cannot afford those bribes are excluded. Bribery also discourages the fulfillment of land laws, leaving citizens unprotected and vulnerable to abuse corruption in urban development is conducted through bribing politicians to obtain development projects" (TI, 2018, p. 7). These misuses of power by the government officials shape the development project into a curse for the project-affected people. In many cases, officials made the artificial problem and forced the public to pay the bribe and common people have nothing to do against them. The respondents also added that they failed to get any remedy to bribery even after reporting the fact to the DC office and surprisingly they discovered a nexus among the officials. The project affected people were orally assured but practically there was no visible action. Rather, the people who reported it first had to face 
many artificial problems such as complexity in documents.

Table 6.10. Switch Over Job $(\mathrm{n}=50)$

\begin{tabular}{|c|c|c|}
\hline Responses & No. of Respondents & $\begin{array}{c}\text { Percentage } \\
(\mathbf{\%})\end{array}$ \\
\hline Yes & 33 & $66.0 \%$ \\
\hline No & 17 & $34.0 \%$ \\
\hline Partially & 00 & $00.0 \%$ \\
\hline Total & 50 & $100 \%$ \\
\hline
\end{tabular}

Source: Field survey, Moulvibazar District, November-December, 2018)

From the field data, it is found that among the Project Affected People (PAP), majority of the respondents $(66 \%)$ switch over their job as they were engaged in agricultural activities before the land acquisition but at present most of them are jobless, unemployed and survive from their fixed deposit and (34\%) respondents replied against this statement (Table 6.10).

Being asked an official claimed:

"There is no government initiative for resettling the jobless \& unemployed people, but now it is the concern of Bangladesh Economic Zone Authority (BEZA) to provide job to these people" (Administrative officials, Interview 5, November 2018).

"Though the land acquisition act provides compensation for lands and fixed assets, there is no condition to evaluate the loss of income and the livelihood of PAPs and no mitigation measures to recover income and livelihood. Thus the consequences of the land acquisition have an extremely negative impact on those who affected by it including the loss of shelter, livelihood, and community" (Atahar, 2013, p. 311).

Though BEZA is committed to providing job to the Project Affected People (PAP) but it is noted that most of the PAP are less educated and they have no qualifications to do office work. So the former land owner will be appointed as a laborer in this project. It is noted that administration does not deal with the after effect of the land acquisition process because in 1982 ordinance, there is no additional assistance to provide aid to the Project Affected People in restoring their livelihood system, and there is no room to include vulnerable groups such as-squatters, matriarchal households, and the elderly and there is no provision for resettlement sites and services. And these limitations provide a chance for the officials to continue their malpractices.

To sum up, the maximum of the acquired land for a development project is agricultural land which is dangerous for the country's sustainable development and it may result in the reduction of the food production together with employment as most of the rural people are working in the agriculture field. Ideally, it is not wise to take any sort of development project which will ruin the country's main strength of the economy. The affected people have not only been suffering by forceful eviction but also being deprived of getting fair compensation. Because compensation of the property is not equivalent to the actual price of the land. All most every person of the affected people wants resettlement by the authority as it will be very 
difficult for them to resettle in another place. On the other hand, there is no watchdog agency for monitoring the activities of Land Acquisition Officers (LAO) which also encourage them to continue malpractices. Most of the rural people are illiterate and they do not know how to make a complaint against the malpractices of those officials and this disability compelled them to tolerate all the unethical activities of the officials.

\section{Concluding Remarks and Recommendations}

To conclude, it is very urgent to put much legal thought on the issues relating to land acquisition so that the incongruities in our system can be eradicated. For the sake of development, land may need to be acquired but the large scale of displacement should be minimized to the possible extent. If not possible there is a necessity to handle it with much attention. The government must work for ensuring the rights of citizens with proper compensation and fairly maintain the procedure. Throughout the study malpractice of bribery is noticed which should be handled iron-handed and a need is felt to establish a watchdog agency to look after the overall land acquisition procedures. The government should increase surveillance on land administration for ensuring fairness in the land acquisition process. Only a fair and corruption-free land administration can deal smoothly with the issues of land acquisition. Development projects are taken for the overall development of the country. For example, the government takes initiatives to establish economic zones for creating employment opportunitiess. But the mismanagement in the land acquisition process creates a new unemployment problem, especially for the uneducated project-affected people. Besides, in most cases, agricultural lands are being acquired which is very alarming for the overall food production of the country and demands special care. These issues should be taken care of in a comprehensive manner to ensure sustainable development in true sense.

The following recommendations should be taken into consideration in the light of research findings are as follows:

- The acquisition of agricultural land should be stopped for ensuring sustainable development otherwise it will create a much negative impact.

- During the acquisition process, the special committee needs to be formulated for monitoring the activities of the Land Acquisition Officer (LAO).

- The land-related document should be kept open to modern technology for reducing the complexity of the acquisition process.

- Legal support for the project-affected people should be increased.

- The valuation of the land should be determined by the present use of the land.

- Assist people to develop alternative options for compensation, restoration of their livelihoods as well as to advocate effectively for themselves in the appeal process or other conflict resolution procedures.

- The government should take initiatives for the land owner who losses their land for the development project. For Example Affected people should be compensated not only for 
the loss of any land, but also for all improvements to the crops, trees, and other natural resources. Besides, they should be compensated for the costs of any disturbance on their remaining land caused by the project. Moreover, training or financial support should be provided to the vulnerable groups if the land acquisition process results in the loss of their livelihoods.

- Moreover, the ethical standard of the administrative officials needs to rise through the motivational program.

\section{References}

Atahar, S. A. (2013). Development Project, Land Acquisition, and Resettlement in Bangladesh; A Quest for Well Formulated National Resettlement and Rehabilitation Policy. International Journal of Humanities and Social Science, 3(7), 306-319. Available from: https://www.researchgate.net/publication/276268916003 [Accessed on $4^{\text {th }}$ October, 2018].

Basu, P. (2007). The political economy of land grab. Economic and Political Weekly, 42(14), 1281-1287. ISSN-0012-9976 (Print) ISSN-2349-8846. Available from: https://www.epw.in/system/files/pdf/2007_42/14/Political_Economy_of_Land_Grab.pdf [Accessed on $18^{\text {th }}$ October, 2018].

Bangladesh Economic Zones Authority (BEZA), (2019). Available from: https://www.beza.gov.bd/economic-zones-site/ [Accessed on $20^{\text {th }}$ March, 2020].

Bangladesh Bureau of Statistics (BBS), (2020). Available from: https://www.bbs.govt.bd/[Accessed on $21^{\text {th }}$ March, 2020].

Cernea, M., \& Mathur, H. M. (2009). Can Compensation Prevent Impoverishment? Reforming Resettlement through Investment and Benefit-Sharing. Oxford University Press. Journal of Refugee Studies, 22(1), 130-132. https://doi.org/10.1093/jrs/fep006

Chan, N. (2003). Land acquisition compensation in China-problems and answers. International Real Estate Review, 6(1), 136-152.

Chandrasekhar, T. C. (2009). Rationality of SEZ in India: Cross country review some lesson to India. Southern Economist, 21(1), 8-10.

FAO, (2009). Compulsory acquisition of land and compensation, FAO Land Tenure Studies. Food and Agriculture Organization of the United Nations, Rome Itality. ISBN 978-92-5-106143-5, Available from: http://www.fao.org/nr/lten/lten_en.htm [Accessed on $11^{\text {th }}$ December, 2018].

FAO, (2008). Compulsory acquisition of land and compensation, FAO Land Tenure Studies. Food and Agriculture Organization of the United Nations, Rome, Itality. Available from: http://www.fao.org/3/i0506e/i0506e00.pdf [Accessed on 25th March , 2020].

Fernanades, et al, (2012). Progress: At whose cost? Development-induced displacement in West Bengal 1947-2000. Guwahati: North Eastern Research Centre.

Islam, M. A. (2019). Law and Practice for Land Acquisition in Bangladesh. Bangladesh 
Journal of Legal Studies. Available from: https://bdjls.org/law-and-practice-for-land-acquisition-in-bangladesh/ [Accessed on $11^{\text {th }}$ April, 2019].

International Institute for Environment and Development. (2018). Special economic zones: engines of development or sites of exploitation. Available from: http://pubs.iied.org/17481IIED [Accessed on $8^{\text {th }}$ July, 2019].

Karmakar, P. (2017). Politics of Development: Land Acquisition and Economic Development in India. Journal of Land and Rural Studies, 5(2) 164-182. https://doi.org/10.1177/2321024917703848

Kurian, N. J. (2000) Widening regional disparities in India: Some indicators. Economic and Political Weekly, 35(7), 538-550.

Landell-Mills, P., \& Serageldin, I. (1991). Governance and the external factor. World Bank Staff Paper. Washington, DC: World Bank. https://doi.org/10.1093/wber/5.suppl_1.303

Mamun, F. A., \& Alam, M. (2019). Land Acquisition for Development Projects: Corruption in Compensation Process Tarnishes Government Image [Online]. Available from: https://www.daily-sun.com/amp/post/367287 [Accessed on $19^{\text {th }}$ April, 2019].

Mazid, M. A. (2019). Special Economic Zones in Bangladesh: A reappraisal approaches. The Financial Express, pp. Available from: https://thefinancialexpress.com. bd/views/ special-economic-zones-in-bangladesh- a-reappraisal-of-approaches-1568473929 [Accessed on $20^{\text {th }}$ November, 2019].

Owen et al, (2015). Land and Political corruption in Sub Saharan Africa. Transparency International

Palmer, D., Fricska, S., \& Wehrmann, B. (2009). Towards Improved Land Governance (Land Tenure Working Paper 11). Available from: http://www.fao.org/3/a-ak999e.pdf [Accessed on $10^{\text {th }}$ February, 2020).

Parwez, S., \& Sen, V. (2016). Special Economic Zone, Land Acquisition, and Impact on Rural India, 2(2) 223-239. https://doi.org/10.1177/2394901516661104

Rahman, S. M. (2013). Compulsory Purchase Procedure in Bangladesh.. Department of Real Estate and Construction Management, Thesis Number: 284, Stockholm. Available from:https://knowledgehub.transparency.org/assets/uploads/kproducts/

Land-Corruption-Topic-Guide-2018-with-picture.pdf [Accessed on $24^{\text {th }}$ March, 2020].

Takwani, C. K. (1980). Lectures on administrative law. Lucknow : Eastern Book Company.

The Acquisition and Requisition of Immovable Property Ordinance, 1982. (issued on 13th April 1982), Bangladesh Gazette, Extraordinary, Ministry of Law, Land Administration and Land Reforms. Available from: https://www.bdlaws.minlaw.gov.bd [Accessed on $9^{\text {th }}$ March, 2020].

The Constitution of the People's Republic of Bangladesh, [latest amendment April, 2008] 


\section{Il Macrothink}

Part III, Article-42.

Transparency International, (2011). Corruption in the Land Sector. (Working paper). Available from: https://reliefweb.int/report/world/corruption-land-sector [Accessed on $21^{\text {th }}$ November, 2018].

Transparency International Bangladesh, survey-presentation-2012 [Accessed on $21^{\text {th }}$ November 2018].

Transparency International, (2018). Land Corruption Topic Guide Compiled by the Anti-Corruption Helpdesk Corruption in the Land Sector. Available from: https://knowledgehub.transparency.org/assets/uploads/kproducts/Land-Corruption-Topic-Gui de-2018-with-picture.pdf [Accessed on $18^{\text {th }}$ April, 2020].

The Daily Star (April 4, 2017) Higher price for acquired land. [Online]. Available from: https://www.thedailystar.net/backpage/higher-price-acquired-land-1386058. [Accessed on $17^{\text {th }}$ April, 2020].

The Dhaka Tribune, (August 17th, 2019). Socio-economic impact of Padma Bridge: A new lease of life for many. Available from: https://www.dhakatribune.com /business/2019/08/17/socio-economic-impact-of-padma-bridge-a-new-lease-of-life-for-many [Accessed on $14^{\text {th }}$ April, 2020]

World Bank, FIAS. (2008). Special economic zones,performance, lessons learned, and implications for zone development. Washington, DC: World Bank

Zaman, M. (2002). Resettlement and development in Indonesia. Journal of Contemporary Asia, 32(2), 255-266. ISSN: 0047-2336 (Print) 1752-7554 (Online). https://doi.org/10.1080/00472330280000161

\section{Copyright Disclaimer}

Copyright for this article is retained by the author(s), with first publication rights granted to the journal.

This is an open-access article distributed under the terms and conditions of the Creative Commons Attribution license (http://creativecommons.org/licenses/by/4.0/). 